\title{
Effects of Back Fascia Relaxation Therapy on Foot Shape of Women in their 30-60s
}

\author{
Mijung $\mathrm{Kim}^{1}$, Seyeon Park ${ }^{2}$, Sooyeon $\mathrm{Oh}^{3 *}$ \\ ${ }^{1}$ Department of Health and Cosmetics, Dongduk Women's University, Seoul, Korea \\ ${ }^{2}$ Department of Applied Chemistry, Dongduk Women's University, Seoul, Korea \\ ${ }^{3}$ Department of Beauty Art, Youngsan University, Busan, Korea
}

\author{
*Corresponding author: Sooyeon Oh, \\ Department of Beauty Art, Youngsan \\ University, 142 Bansongsunhwan-ro, \\ Haeundae-gu, Busan 48015, Korea \\ Tel.: +82515407311 \\ Fax: +82515407334 \\ Email: osy1459@ysu.ac.kr
}

Received November 10, 2016

Revised June 8, 2017

Accepted July 6, 2017

Published December 30, 2017

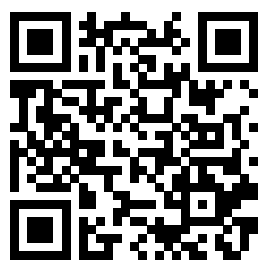

\begin{abstract}
Purpose: In this study, we investigated whether back fascia relaxation therapy could affect the foot shape of adult women in their 30-60s and also checked whether there were differences according to the frequency of back fascia therapy or participant age. Methods: Based on the frequency of therapy (once a week vs. twice a week) and age (30-40s vs. 50-60s), 34 healthy women in their 30-60s living in Busan were divided into groups and underwent back fascia relaxation therapy six times. Footprinting was performed before and after the experiment (i.e., therapy) to confirm changes in the foot shape. Through footprinting, foot length I, foot length II, foot width, calcaneus width, heel angle, arch angle, hallux angle, toe angle, and eversion angle were measured. To analyze data, independent $t$-test, descriptive statistics, and two-way analysis of variance (ANOVA) of repeated measurements were performed using Statistical Package for the Social Sciences (SPSS) 20.0. Results: The back fascia relaxation therapy affected the footprint appearance. The calcaneus width $(p<0.01, p<0.001)$, arch angle $(p<0.001, p<0.01)$, and hallux angle $(p<0.01$, $p<0.01$ ) were significantly different in both feet according to the measuring time. Further, foot length II $(p<0.05)$, heel angle $(p<0.05)$, and eversion angle $(p<0.01)$ were significantly different in the right foot. However, there was no significant change in foot length I, foot width, or toe angle. Moreover, these results were consistent regardless of age or frequency of therapy. Conclusion: Back fascia relaxation therapy changed the foot shape of adult women and was found to be highly relevant to the spinal reflex of the foot.
\end{abstract}

Keywords: Fascia, Reflex, Footprint, Arch angle, Hallux angle

\section{Introduction}

현대사회에 들어서면서 여성의 위치와 역할은 사회전반적인 면에서 급속히 변모하고 있다(Ryu \& Han, 2016). 특히 30-60 대 성인 여성의 경우, 생애 주기를 가정과 사회 생활에서 막중 한 책임을 맡는 시기와 신체와 역할에서 변화를 경험하는 시기 를 통해 나눌 수 있는데(Kim, 2009), 이 때 주목할 만한 것으 로 갱년기를 들 수 있다. 여성에게 갱년기는 임신 기능이 상실 되는 시기인데 이 때 일어나는 현상 중의 하나가 폐경이다(Ahn et al., 2005). 한의학에서는 여성의 생리적인 변화 주기를 7 로 하여 칠칠세(七七歲)인 49 세에 폐경이 온다고 하였으며 출산율
의 변수로 사용되는 연령별 출산율의 대상도 49 세까지만 감안 하고 있다(Ahn et al., 2005; Hwang \& Lee, 2012). 또한, 우 리나라의 국민노후보장패널과 미국의 Health and Retirement Study (HRS), 영국의 English Longitudinal Study of Ageing (ELSA), 유럽연합의 Survey of Health, Ageing and Retirement in Europe (SHARE)도 50세 이상을 중고령 인구로 설정하고 있다(Kang \& Lim, 2009). 이를 통해 30-60대 성인 여성을 연령에 따라 구분할 경우, 50 세를 기준으로 나눌 수 있을 것이다.

발은 신체의 하중과 지지, 이동에 관여하기에 인체의 균형에서 주요한 부위이다. 내·외부적인 영향이 발에 가해지게 되면 인체 


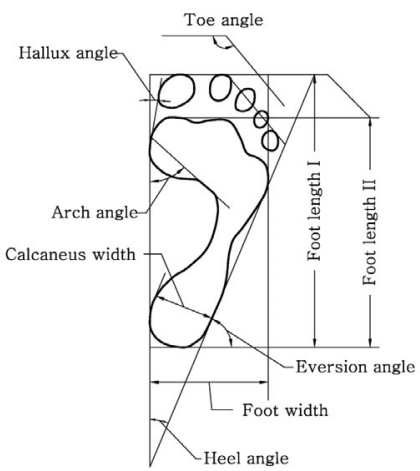

Figure 1. Footprint measurement.

Footprint was measured by Clarke's footprint angle method. The following variables were measured: foot length I, foot length II, foot width, calcaneus width, heel angle, arch angle, hallux angle, toe angle, and eversion angle.

의 해부학적 질서에 변화가 나타나, 족관절부터 무릎과 고관절, 나아가 척추에까지 변형이 나타나게 된다(Hyong, 2008). 또한 발바닥에는 인체의 모든 기관들이 축소 또는 투영되어 있어 특정 부위를 자극하면 연결되어 있는 신체 기관에 영향을 준다(Heo et al., 2013; quoted in Jeong, 2004; Kim \& Kim, 2003). 이 러한 맥락에서 역으로 신체 특정 기관에 마사지를 하였을 때 발 의 모양이 변화하기도 한다(Song et al., 2010).

인체의 유기적 연결에 대한 근거로 제시되는 이론에는 근막경 선이론이 있다. 근막(fascia)은 머리부터 발끝까지 세 겹으로 이 어진 강한 결합조직인데 collagen, elastin, polysaccharide gel complex, ground substance로 구성되어 있어 외부 자극으로 부터 완충작용을 할 수 있다(Ham, 1999). 이러한 근막을 통해 역학적인 동작과 긴장을 전달하는 경로를 근막경선(myofascial meridian)이라 하고 7개의 기능선이 있다(quoted in Song et al., 2005). 그 중에 천층후면근막경선(superficial back line) 은 발바닥에서 시작하여 후면을 지나 이마에 이르는 기능선으로 등과 발의 유기적 관련성을 뒷받침한다(quoted in Song et al., 2005).

지금까지 진행되었던 선행 연구들을 살펴보면, 중년 여성을 대 상으로 한 갱년기 관련 연구가 많았다(Jung et al., 2009; Kim $\&$ Bae, 2012; Park \& Choi, 2014). 그리고 발마사지와 족욕 등 발에 관련된 연구 또한 다수 진행되었다(Seo \& Sohng, 2011; Yoon \& Choi, 2013). 근막이완요법도 물리치료나 도수치료를 중심으로 많은 연구가 있는 상황이다(Kim et al., 2014; Seo et al., 2010; Seo et al., 2002). 그러나 30-60대의 성인 여성들 을 관리 빈도와 연령으로 구분하여 등 근막이완요법의 마사지를 시행하는 연구나 그에 따라 발의 모양이 변화하는지를 살펴보는 연구는 미진한 상태이다.

따라서 본 연구는 등 부위에 시행하는 근막이완요법이 관리 빈

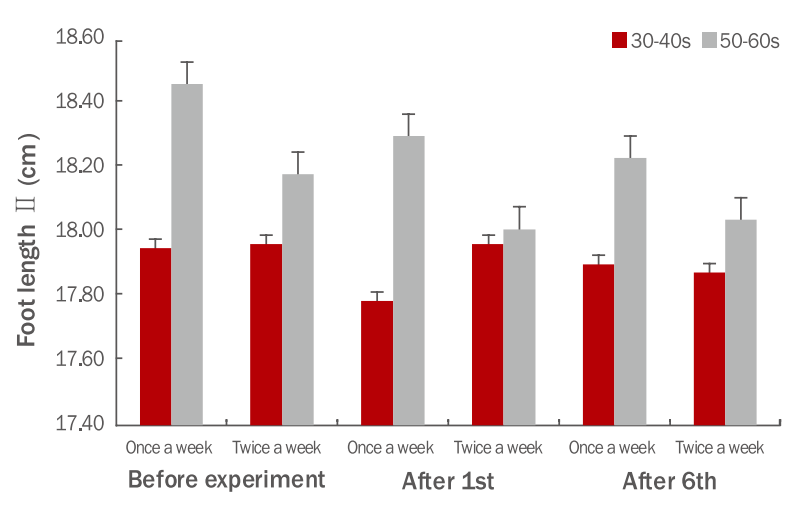

Figure 2. Descriptive analysis of foot length II of the right foot. Foot length II of the right foot was greater in women in their 50-60s than in those in their 30-40s. The effects of before vs. after therapy were greater in women in their 50-60s than in those in their 30-40s.

도와 연령에 따라 성인 여성의 발 형태를 변화시키는지를 알아보 고 이에 따른 등과 발과의 관계를 살펴보고자 한다.

\section{Methods}

\section{1. 연구대상 및 절차}

본 연구는 부산에 거주하고 있는 질병을 않고 있지 않는 30-60대의 성인 여성을 대상으로 진행하였다. 2014년 2-3월 에 거쳐 예비 실험을 통해서 연구 방법에 따른 효과를 확인한 후 본 실험을 진행하였다. 본 실험은 2014년 4월 7일부터 5 월 13 일 까지 6주간 각 6 회씩 진행하였다. 대상자는 30-40대의 여성 16 명을 관리 빈도(주1회, 주2회)에 따라 각 8명씩 나누고 50-60대 의 여성 18 명도 동일한 방식으로 각 9 명씩 구분하였다. 대상자 들에게 등 근막이완요법을 시행하여 관리 빈도에 따른 변화와 연 령에 따른 변화를 함께 살펴보았다. 등 근막이완요법의 시행은 $18-22^{\circ} \mathrm{C}$ 의 온도, $40-60 \%$ 의 습도가 유지되는 환경에서 등의 후 면에서 시작하여 측면에 걸쳐서 진행하였다. 족문은 등 근막이완 요법의 시행 전과 후에 측정하였다.

\section{2. 연구도구}

족문은 Clarke (1933)가 개발한 footprint angle 방법으로, 족문기(foot print; Parenco, Korea)를 이용하여 측정하였다. 족문의 측정값은 족장 I (foot length I), 족장 II (foot length II), 족폭(foot width), 종골폭(calcaneus width), 종골각(heel angle), 아치각(arch angle), 모지각(hallux angle), 족선각(toe angle), 외번각(eversion angle) 총 9가지이다(Figure 1).

측정방법은 족문기의 한쪽에 잉크를 바르고 반대편에 종이를 얹은 후 대상자의 몸이 한쪽으로 치우치지 않도록 하여 두 손을 
잡아주고 족문기에 올라서게 한 다음, 무릎을 살짝 굽혔다가 편 후 한발씩 차례로 뗀다. 족문은 자와 각도기를 이용하여 길이와 각도값을 측정하였다.

\section{3. 자료분석}

본 연구 자료의 분석과 처리는 SPSS WIN 20.0 (IBM, USA) 를 통해서 진행하였다. 동질성 검증을 위해서 독립표본 $t$ 검정을 시행하였고, 등 근막이완요법의 영향은 기술통계와 반복측정 이 원분산분석(two-way ANOVA of repeated measures)을 실시 하였다.

\section{Results and Discussion}

\section{1. 연구대상자의 인구통계학적 특성}

본 연구의 대상자에 대한 인구통계학적 특성을 살펴보면, 직 업은 관리 빈도 주 1 회군에서 가정주부의 비율이 높게 나타나
고 주 2 회군에서는 자영업의 비율이 많았다. 연령의 측면에서 보 면 30-40대에서는 교사의 비율이 37.5\%로 높았고, 50-60대 에서는 자영업이 $38.9 \%$ 로 높게 나타났다. 결혼 여부는 주1회군 과 2회군 모두 기혼이라는 응답이 높았고, 30-40대는 미혼과 기 혼 비율이 비슷했던 반면에 50-60대는 $77.8 \%$ 가 기혼이라고 답 하였다. 월 소득은 주1회군의 $76.5 \%$ 가 200-400만원이라고 하 였고 주2회군 35.3\%가 400-600만원이라고 응답하였다. 연령 의 측면에서 보면 30-40대와 50-60대 모두 200-400만원이라 는 응답이 많았고 다음으로 400-600만원이라고 답하였다. 몸무 게는 주 1 회군과 주 2 회군 모두 $50 \mathrm{~kg}$ 대라는 응답이 많았다. 연령 의 측면에서 보면 30-40대는 $50 \mathrm{~kg}$ 대 이하라는 응답이 $93.8 \%$ 이었고, 50-60대는 50-60 kg대라는 응답이 83.3\%로 높았다. 키는 155-160 cm 미만이라는 응답이 주1회군, 주2회군 모두에 서 절반 정도를 차지하였다. 연령의 측면에서 보면, 30-40대에 서 155-165 cm 미만이라는 응답이 75.0\%를 차지하였고 50-60 대에서는 150-160 cm 미만이라는 응답이 $83.3 \%$ 를 차지하였다 (Table 1).

Table 1. Sample characteristics based on the frequency of back fascia therapy and age

$(n=34)$

\begin{tabular}{|c|c|c|c|c|c|}
\hline \multirow{2}{*}{ Variable } & & \multicolumn{2}{|c|}{ Frequency of therapy } & \multicolumn{2}{|c|}{ Age } \\
\hline & & Once a week & Twice a week & $30-40 s$ & $50-60 s$ \\
\hline \multirow{6}{*}{ Occupation } & Office job & $3(17.6 \%)$ & $1(5.9 \%)$ & $2(12.5 \%)$ & $2(11.1 \%)$ \\
\hline & Management & $0(0.0 \%)$ & $1(5.9 \%)$ & $1(6.3 \%)$ & $0(0.0 \%)$ \\
\hline & Sales & $1(5.9 \%)$ & $2(11.8 \%)$ & $1(6.3 \%)$ & $2(11.1 \%)$ \\
\hline & Self-employment & $3(17.6 \%)$ & 7 (41.2\%) & $3(18.8 \%)$ & 7 (38.9\%) \\
\hline & Teacher & $4(23.5 \%)$ & $4(23.5 \%)$ & $6(37.5 \%)$ & $2(11.1 \%)$ \\
\hline & Housemaker & $6(35.3 \%)$ & $2(11.8 \%)$ & $3(18.8 \%)$ & $5(27.8 \%)$ \\
\hline \multirow{3}{*}{ Marital status } & Single & 5 (29.4\%) & $4(23.5 \%)$ & 8 (50.0\%) & $1(5.6 \%)$ \\
\hline & Married & 9 (52.9\%) & $12(70.6 \%)$ & 7 (43.8\%) & $14(77.8 \%)$ \\
\hline & NA & $3(17.6 \%)$ & $1(5.9 \%)$ & $1(6.3 \%)$ & $3(16.7 \%)$ \\
\hline \multirow{6}{*}{$\begin{array}{l}\text { Monthly income } \\
\text { (10,000 won) }\end{array}$} & 100-200 under & 1 (5.9\%) & $2(11.8 \%)$ & $2(12.5 \%)$ & $1(5.6 \%)$ \\
\hline & 200-400 under & $13(76.5 \%)$ & $3(17.6 \%)$ & $8(50.0 \%)$ & $8(44.4 \%)$ \\
\hline & 400-600 under & $2(11.8 \%)$ & $6(35.3 \%)$ & $3(18.8 \%)$ & $5(27.8 \%)$ \\
\hline & $600-800$ under & $1(5.9 \%)$ & $3(17.6 \%)$ & $2(12.5 \%)$ & $2(11.1 \%)$ \\
\hline & $800-1,000$ under & $0(0.0 \%)$ & $1(5.9 \%)$ & $0(0.0 \%)$ & $1(5.6 \%)$ \\
\hline & 1,000 over & $0(0.0 \%)$ & $2(11.8 \%)$ & $1(6.3 \%)$ & $1(5.6 \%)$ \\
\hline \multirow{4}{*}{$\begin{array}{l}\text { Weight } \\
\text { (kg) }\end{array}$} & 50 under & 1 (5.9\%) & $2(11.8 \%)$ & $3(18.8 \%)$ & $0(0.0 \%)$ \\
\hline & $50-60$ under & $9(52.9 \%)$ & 9 (52.9\%) & $12(75.0 \%)$ & $6(33.3 \%)$ \\
\hline & $60-70$ under & $5(29.4 \%)$ & $4(23.5 \%)$ & $0(0.0 \%)$ & 9 (50.0\%) \\
\hline & $70-80$ under & 2 (11.8\%) & $2(11.8 \%)$ & $1(6.3 \%)$ & $3(16.7 \%)$ \\
\hline \multirow{5}{*}{$\begin{array}{l}\text { Height } \\
\text { (cm) }\end{array}$} & 150 under & $1(5.9 \%)$ & $1(5.9 \%)$ & $2(12.5 \%)$ & $0(0.0 \%)$ \\
\hline & $150-155$ under & $2(11.8 \%)$ & $4(23.5 \%)$ & $0(0.0 \%)$ & $6(33.3 \%)$ \\
\hline & $155-160$ under & 9 (52.9\%) & $8(47.1 \%)$ & $8(50.0 \%)$ & $9(50.0 \%)$ \\
\hline & $160-165$ under & 4 (23.5\%) & $3(17.6 \%)$ & 4 (25.0\%) & $3(16.7 \%)$ \\
\hline & $165-170$ under & $1(5.9 \%)$ & $1(5.9 \%)$ & $2(12.5 \%)$ & $0(0.0 \%)$ \\
\hline Total & & 17 (100.0\%) & 17 (100.0\%) & 16 (100.0\%) & 18 (100.0\%) \\
\hline
\end{tabular}



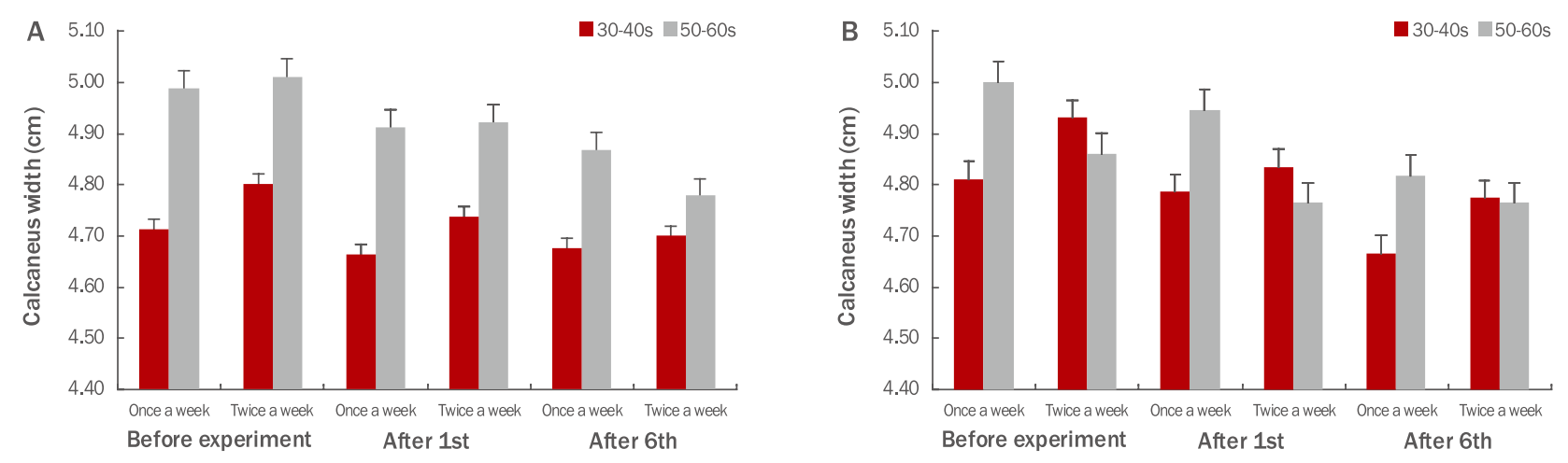

Figure 3. Descriptive analysis of the calcaneus width in both feet.

(A) Calcaneus width of the left foot. Effects of therapy on the calcaneus width of the left foot were greater in women in their 50-60s than in those in their 30-40s, and the calcaneus width of the left foot consecutively decreased from before the start of therapy to after the sixth round of therapy. (B) Calcaneus width of the right foot. The calcaneus width of the right foot in women in their 30-40s and 50-60s consecutively decreased from before the start of therapy to after the sixth round of therapy. Moreover, change in the calcaneus width of the right foot was the greatest in women in their 50-60s undergoing therapy once a week.

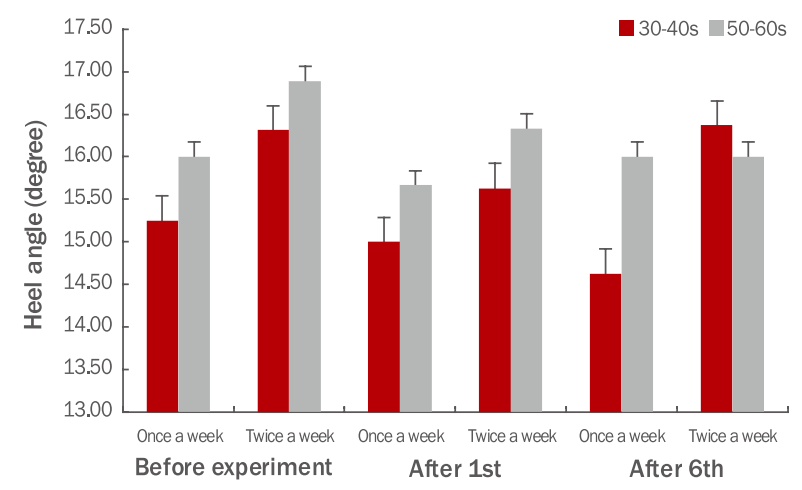

Figure 4. Descriptive analysis of the heel angle of the right foot. The heel angle of the right foot in women in their 30-40s undergoing therapy once a week and in those in their 50-60s undergoing therapy twice a week consecutively decreased from before the start of therapy to after the sixth round of therapy.

\section{2. 족문 측정 결과}

실험을 실시하기 전에 족문기에 의한 측정값인 족장 $\mathrm{I}$, 족장 II, 족폭, 종골폭, 종골각, 아치각, 모지각, 족선각, 외번각들이 관리 빈도와 연령에 대해서 동질한지를 알아보기 위해 독립표본 $t$ 검정을 실시하였으며 동질한 집단이라는 결과를 얻었다.

\section{1) 족장 । 에 대한 변화 비교}

등 근막이완요법이 왼발의 족장 I 에 미치는 영향을 알아보기 위해 기술통계와 반복측정 이원분산분석을 실시하였다. 그 결과 를 보면, 왼발의 족장 I 에서 연령, 관리 빈도, 측정 시기에 대한 주 효과와 연령과 관리 빈도의 상호작용효과, 측정 시기와 연령의 상호작용효과, 측정 시기와 관리 빈도의 상호작용효과, 측정 시기
및 연령과 관리 빈도의 상호작용효과에서 통계적인 유의성이 나 타나지 않았다(Appendix 1). 오른발의 족장 I 도 효과에 대한 측 정 항목에서 통계적 유의성이 확인되지 않았다(Appendix 2).

2) 족장 ॥ 에 대한 변화 비교

등 근막이완요법이 왼발의 족장 II 에 미치는 영향을 알아보기 위해 기술통계와 반복측정 이원분산분석을 실시하였다. 이에 결 과를 살펴보면, 왼발의 족장 II 는 연령, 관리 빈도, 측정 시기의 주 효과와 연령과 관리 빈도의 상호작용효과, 측정 시기와 연령 의 상호작용효과, 측정 시기와 관리 빈도의 상호작용효과, 측정 시기 및 연령과 관리 빈도의 상호작용효과에서 통계적인 유의성 이 나타나지 않았다(Appendix 3).

이에 반해 오른발의 족장 II 에 대한 기술통계를 보면, 전반적 으로 30-40대보다 50-60대의 족장 II 의 길이가 길고 시간에 따 른 변화폭도 50-60대에서 좀더 컸다(Figure 2). 반복측정 이원 분산분석의 결과에서도 측정 시기 $(F=3.903 ; p<0.05)$ 에 대해 주 효과가 나타났기에 통계적으로 유의미한 차이를 알아보기 위해 Bonferroni로 조정한 다중비교를 하였다. 실험 전과 실험 1회 후까지는 차이가 보였지만 1 회 이후로는 차이가 나타나지 않았 다. 이를 통해 실험 1 회 이후의 효과가 6 회까지 지속되었다는 것 을 알 수 있다(Table 2). 반면에 연령, 관리 빈도의 주 효과와 연 령과 관리 빈도의 상호작용효과, 측정 시기와 연령의 상호작용효 과, 측정 시기와 관리 빈도의 상호작용효과, 측정 시기 및 연령 과 관리 빈도의 상호작용효과는 통계적으로 유의미하지 않은 것 으로 나타났다(Appendix 4). 이것은 등 근막이완요법의 시행이 연령이나 관리 빈도에 관계없이 족장 II 의 변화에 효과가 있다는 것을 의미하는 것이다. 
3) 족폭에 대한 변화 비교

등 근막이완요법이 왼발의 족폭에 미치는 영향을 알아보기 위해 기술통계와 반복측정 이원분산분석을 실시하였다. 그 결과는 연령, 관리 빈도, 측정 시기의 주 효과와 연령과 관리 빈도의 상호작용효
과, 측정 시기와 연령의 상호작용효과, 측정 시기와 관리 빈도의 상 호작용효과, 측정 시기 및 연령과 관리 빈도의 상호작용효과에서 통 계적으로 유의미하지 않았다(Appendix 5). 오른발의 족폭에 대한 측 정 항목에서도 통계적인 유의성이 나타나지 않았다(Appendix 6).

Table 2. Two-way ANOVA of repeated measures and multiple comparisons using the Bonferroni method on effects of back fascia relaxation therapy

\begin{tabular}{|c|c|c|c|c|c|c|c|}
\hline \multicolumn{3}{|l|}{ Variable } & S.S & df & M.S. & $F$ & $p$ \\
\hline \multirow{9}{*}{$\begin{array}{l}\text { Measuring time of two- } \\
\text { way ANOVA for repeated } \\
\text { measures }\end{array}$} & \multicolumn{2}{|c|}{ Foot length $\Pi$ (of the right foot) } & 0.338 & 2 & 0.169 & $3.903^{*}$ & 0.025 \\
\hline & \multicolumn{2}{|c|}{ Calcaneus width (of the left foot) } & 0.259 & 2 & 0.129 & $6.916^{* *}$ & 0.002 \\
\hline & \multicolumn{2}{|c|}{ Calcaneus width (of the right foot) } & 0.384 & 1.631 & 0.235 & $12.604^{* * *}$ & 0.000 \\
\hline & \multicolumn{2}{|c|}{ Heel angle (of the right foot) } & 3.941 & 2 & 1.970 & $3.459^{*}$ & 0.038 \\
\hline & \multicolumn{2}{|c|}{ Arch angle (of the left foot) } & 169.789 & 2 & 84.895 & $10.366^{* * *}$ & 0.000 \\
\hline & \multicolumn{2}{|c|}{ Arch angle (of the right foot) } & 163.427 & 2 & 81.713 & $7.741^{* *}$ & 0.001 \\
\hline & \multicolumn{2}{|c|}{ Hallux angle (of the left foot) } & 54.000 & 2 & 27.000 & $6.312^{* *}$ & 0.003 \\
\hline & \multicolumn{2}{|c|}{ Hallux angle (of the right foot) } & 65.364 & 2 & 32.682 & $6.502^{* *}$ & 0.003 \\
\hline & \multicolumn{2}{|c|}{ Eversion angle (of the right foot) } & 69.589 & 2 & 34.795 & $5.615^{* *}$ & 0.006 \\
\hline \multicolumn{2}{|l|}{ Variable } & (I) factor & (J) factor & \multicolumn{2}{|c|}{ M.Diff. (I-J) } & S.E. & $p$ \\
\hline \multirow{27}{*}{$\begin{array}{l}\text { Multiple comparisons } \\
\text { using Bonferroni method }\end{array}$} & \multirow{3}{*}{$\begin{array}{l}\text { Foot length } \Pi \\
\text { (of the right foot) }\end{array}$} & \multirow{2}{*}{ Before experiment } & After 1st & \multicolumn{2}{|c|}{$0.121^{*}$} & 0.046 & 0.041 \\
\hline & & & After 6th & \multicolumn{2}{|c|}{0.123} & 0.052 & 0.073 \\
\hline & & After 1st & After 6th & \multicolumn{2}{|c|}{0.002} & 0.053 & 1.000 \\
\hline & \multirow{3}{*}{$\begin{array}{l}\text { Calcaneus width } \\
\text { (of the left foot) }\end{array}$} & \multirow{2}{*}{ Before experiment } & After 1st & \multicolumn{2}{|c|}{0.070} & 0.037 & 0.205 \\
\hline & & & After 6th & & $23^{* *}$ & 0.036 & 0.005 \\
\hline & & After 1st & After 6th & & 53 & 0.026 & 0.139 \\
\hline & \multirow{3}{*}{$\begin{array}{l}\text { Calcaneus width } \\
\text { (of the right foot) }\end{array}$} & \multirow{2}{*}{ Before experiment } & After 1st & & 70 & 0.028 & 0.058 \\
\hline & & & After 6th & & $50^{* *}$ & 0.036 & 0.001 \\
\hline & & After 1st & After 6th & & $80^{* *}$ & 0.024 & 0.007 \\
\hline & \multirow{3}{*}{$\begin{array}{l}\text { Heel angle } \\
\text { (of the right foot) }\end{array}$} & \multirow{2}{*}{ Before experiment } & After 1st & & $57^{*}$ & 0.169 & 0.034 \\
\hline & & & After 6th & & 63 & 0.188 & 0.190 \\
\hline & & After 1st & After 6th & & & 0.192 & 1.000 \\
\hline & & & After 1st & & $35^{* *}$ & 0.770 & 0.005 \\
\hline & Arch angle & Before experiment & After 6th & & $37^{* * *}$ & 0.596 & 0.000 \\
\hline & & After 1st & After 6th & & & 0.708 & 1.000 \\
\hline & & & After 1st & & $03^{*}$ & 0.826 & 0.015 \\
\hline & $\begin{array}{l}\text { Arch angle } \\
\text { (of the right foot) }\end{array}$ & Before experiment & After 6th & & $44^{*}$ & 0.893 & 0.010 \\
\hline & & After 1st & After 6th & & & 0.624 & 1.000 \\
\hline & & Rofore oxporiment & After 1st & & 95 & 0.554 & 0.079 \\
\hline & $\begin{array}{l}\text { Hallux angle } \\
\text { (of the left foot) }\end{array}$ & Betore experıment & After 6th & & $12^{* *}$ & 0.497 & 0.005 \\
\hline & & After 1st & After 6th & & 17 & 0.451 & 1.000 \\
\hline & & & After 1st & & 11 & 0.505 & 0.107 \\
\hline & $\begin{array}{l}\text { Hallux angle } \\
\text { (of the right foot) }\end{array}$ & Before experiment & After 6th & & $58^{* *}$ & 0.505 & 0.002 \\
\hline & & After 1st & After 6th & & 47 & 0.616 & 0.538 \\
\hline & & Dofore provimont & After 1st & & $46^{* *}$ & 0.488 & 0.006 \\
\hline & Eversion angle & Betore experiment & After 6th & & $47^{*}$ & 0.692 & 0.037 \\
\hline & & After 1st & After 6th & & & 0.616 & 1.000 \\
\hline
\end{tabular}

ANOVA, analysis of variance; S.S., sum of square; df, degree of freedom; M.S., mean square; M.Diff., mean difference; S.E., standard error; ${ }^{*} p<0.05 ;{ }^{* *} p<0.01 ;{ }^{* * *} p<0.001$. 

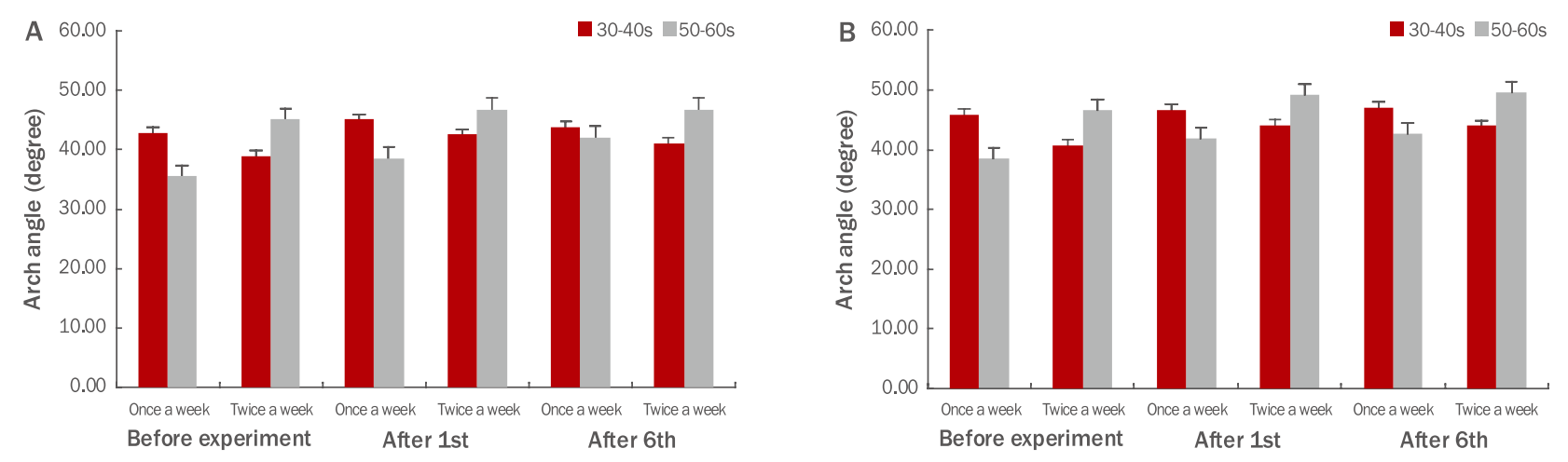

Figure 5. Descriptive analysis of the arch angle in both feet.

(A) Arch angle of the left foot. The arch angle of the left foot in women in their 50-60s consecutively increased from before the start of therapy to after the sixth round of therapy. In particular, effects of therapy on the arch angle of the left foot in women in their 50-60s undergoing therapy once a week were greater than in those in their 50-60s undergoing therapy twice a week. (B) Arch angle of the right foot. The arch angle of the right foot in women in their 30-40s and in those in their 50-60s increased from before the start of therapy to after the sixth round of therapy. Moreover, the change was the greatest in women in their 50-60s undergoing therapy once a week.
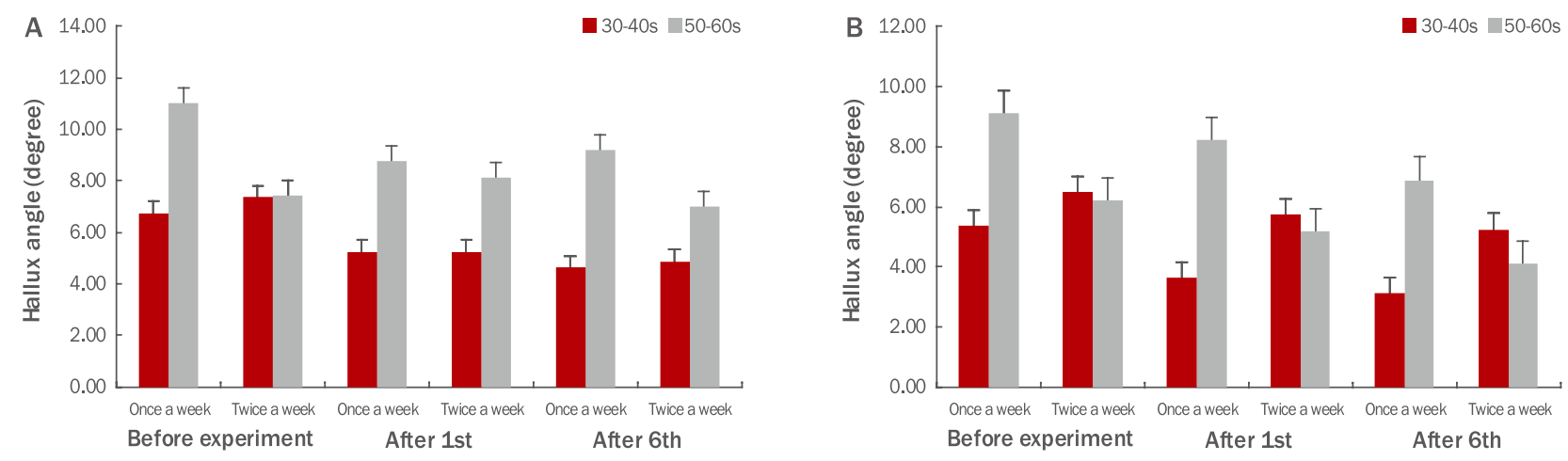

Figure 6. Descriptive analysis of the hallux angle in both feet.

(A) Hallux angle of the left foot. The hallux angle of the left foot in women in their 50-60s was larger than that in those in their 3040s. The hallux angle of the left foot in women in their 30-40s consecutively decreased from before the start of therapy to after the sixth round of therapy. (B) Hallux angle of the right foot. The hallux angle of the right foot in women in their 30-40s and that in those in their 50-60s consecutively decreased from before the start of therapy to after the sixth round of therapy. Moreover, the change was the greatest in women in their 30-40s undergoing therapy once a week.

\section{4) 종골폭에 대한 변화 비교}

등 근막이완요법이 왼발의 종골폭에 미치는 영향을 알아보 기 위해 기술통계와 반복측정 이원분산분석을 실시하였다. 기 술통계를 보면, 30-40대보다 50-60대 변화의 폭이 컸으며, 실 험 전부터 6 회까지 순차적으로 50-60대의 종골폭이 감소하였 다(Figure $3 \mathrm{~A})$. 반복측정 이원분산분석을 통해서는 측정 시기 $(F=6.916 ; p<0.01)$ 의 주 효과가 나타났다. 측정 시기 간의 통계 적 유의미성을 알아보기 위해 Bonferroni로 조정하여 다중비교 를 한 결과, 왼발의 종골폭이 실험 1 회까지는 효과가 나타나지 않았지만 실험 6 회부터 효과가 나타났다(Table 2). 이에 반해 연 령, 관리 빈도의 주 효과와 연령과 관리 빈도의 상호작용효과, 측정 시기와 연령의 상호작용효과, 측정 시기와 관리 빈도의 상
호작용효과, 측정 시기 및 연령과 관리 빈도의 상호작용효과는 통계적으로 유의미한 차이가 나타나지 않았다(Appendix 7).

오른발의 종골폭에 대한 기술통계를 보면, 30-40대와 50-60 대 모두 실험 전에서부터 6 회까지 종골폭이 순차적으로 감소하 였는데 50-60대의 1회군에서 변화의 폭이 가장 크게 나타났다 (Figure $3 \mathrm{~B}$ ). 또한, 반복측정 이원분산분석의 결과에서는 측정 시기 $(F=12.604 ; p<0.001)$ 의 주 효과가 나타났다. 따라서 측정 시기 간의 통계적 유의미성을 알아보기 위해 Bonferroni로 조 정한 다중비교의 결과를 살펴보았다. 실험 전과 실험 1 회 간에는 차이가 나타나지 않았지만 실험 전과 실험 6 회 사이 그리고 실 험 1 회와 실험 6 회 간에서 유의성 있는 효과가 보였다. 이를 통 해 실험에 대한 효과가 실험 1 회 이후에 나타났음을 알 수 있다 


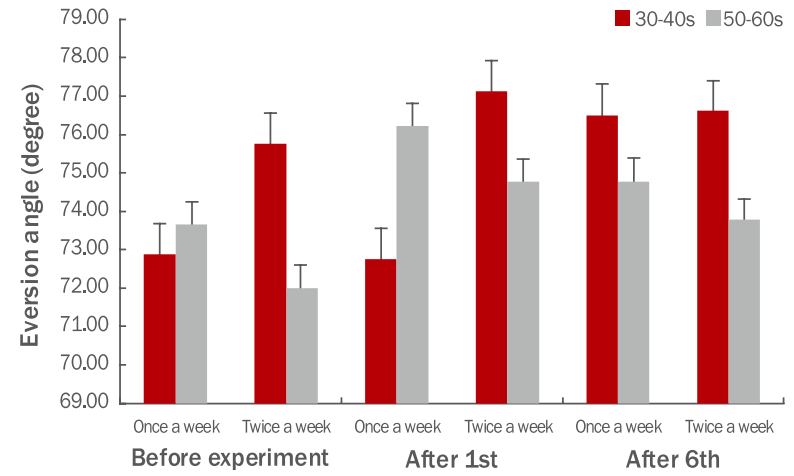

Figure 7. Descriptive analysis of the eversion angle of the right foot. The eversion angle of the right foot in women in their 30-40s and those in their 50-60s increased from before the start of therapy to after the sixth round of therapy.

(Table 2). 이에 반해 연령, 관리 빈도의 주 효과와 연령과 관리 빈도의 상호작용효과, 측정 시기와 연령의 상호작용효과, 측정 시기와 관리 빈도의 상호작용효과, 측정 시기 및 연령과 관리 빈 도의 상호작용효과에서는 통계적으로 유의미한 차이가 나타나지 않았다(Appendix 8).

이것을 통해 등 근막이완요법의 효과가 종골폭에서는 일정 횟 수 후에 나타나며 좌우가 동시에 나타나는 것으로 보아 시행 방 법과 발 사이의 관련성이 높은 것으로 짐작된다.

\section{5) 종골각에 대한 변화 비교}

등 근막이완요법이 왼발의 종골각에 미치는 영향을 알아보기 위해 기술통계와 반복측정 이원분산분석을 실시하였다. 그 결 과, 연령과 관리 빈도, 측정 시기의 주 효과와 연령과 관리 빈도 의 상호작용효과, 측정 시기와 연령의 상호작용효과, 측정 시기 와 관리 빈도의 상호작용효과, 측정 시기 및 연령과 관리 빈도의 상호작용효과에서 통계적으로 유의미한 차이가 나타나지 않았다 (Appendix 9).

이에 반해 오른발의 종골각에서는 효과가 나타났다. 먼저 기 술통계를 보면, 30-40대에서는 주1회군이, 50-60대에서는 주2 회군이 실험 전에서 실험 6 회까지 순차적으로 종골각이 감소하 였다(Figure 4). 반복측정 이원분산분석의 결과에서는 측정 시 기 $(F=3.459 ; p<0.05)$ 에 따른 주 효과가 나타났기에 통계적 유 의성을 알아보기 위해 Bonferroni로 조정한 다중비교를 하였다. 오른발의 종골각은 실험 전과 실험 1 회 간의 차이가 나타났지만 1 회 이후로는 차이가 존재하지 않아 1 회의 효과가 6 회까지 지속 되었음을 알 수 있다(Table 2). 이와 달리, 연령, 관리 빈도의 주 효과와 연령과 관리 빈도의 상호작용효과, 측정 시기와 연령의 상호작용효과, 측정 시기와 관리 빈도의 상호작용효과, 측정 시 기 및 연령과 관리 빈도의 상호작용효과는 통계적으로 유의미한
차이가 보이지 않았다(Appendix 10). 이로써 등 근막이완요법의 시행이 연령이나 관리 빈도와 상관없이 종골각의 변화에 효과가 있었음을 알 수 있다.

6) 아치각에 대한 변화 비교

등 근막이완요법이 왼발의 아치각에 미치는 영향을 알아보기 위해 기술통계와 반복측정 이원분산분석을 실시하였다. 기술통 계를 살펴보면, 50-60대가 순차적으로 아치각이 증가하였는데 주1회군에서 좀더 변화의 폭이 컸다(Figure $5 \mathrm{~A}$ ). 반복측정 이원 분산분석을 통한 결과를 보면, 측정 시기 $(F=10.366 ; p<0.001)$ 에서 주 효과가 나타났고 측정 시기에 대한 통계적 유의성을 알 아보기 위해 Bonferroni로 조정된 다중비교를 시행하였다. 이 에 실험 전에 대해 실험 1 회와 실험 6 회는 각각 유의성이 확인되 었지만 실험 1 회에 대해 실험 6 회는 차이가 존재하지 않아 실험 1 회에서 나타난 효과가 6 회까지 지속된 것을 알 수 있다(Table 2). 이에 반해 연령, 관리 빈도의 주 효과와 연령과 관리 빈도의 상호작용효과, 측정 시기와 연령의 상호작용효과, 측정 시기와 관리 빈도의 상호작용효과, 측정 시기 및 연령과 관리 빈도의 상 호작용효과에서는 통계적으로 유의미한 차이가 보이지 않았다 (Appendix 11).

오른발의 아치각에 대한 기술통계를 보면, 30-40대와 50-60 대에서 실험 전에 비해 아치각이 증가하였는데 50-60대의 주1 회군에서 가장 크게 변화하였다(Figure $5 \mathrm{~B}$ ). 반복측정 이원분 산분석을 통한 결과를 보면, 측정 시기 $(F=7.741 ; p<0.01)$ 에 대 한 주 효과가 나타났다. 이에 통계적 유의성을 알아보기 위해 Bonferroni로 조정된 다중비교를 시행한 결과, 실험 전과 실험 1 회에서 차이가 나타났다. 그리고 실험 6 회에 대해서도 유의성 이 존재하였으나 실험 1 회와 실험 6 회에서는 차이가 존재하지 않 아 실험 1 회에서 나타난 효과가 6 회까지 지속되었음을 알 수 있 다(Table 2). 이와 달리 연령, 관리 빈도의 주 효과와 연령과 관 리 빈도의 상호작용효과, 측정 시기와 연령의 상호작용효과, 측 정 시기와 관리 빈도의 상호작용효과, 측정 시기 및 연령과 관리 빈도의 상호작용효과는 통계적으로 유의미하지 않게 나타났다 (Appendix 12).

이 결과를 통해 근막이완요법의 효과가 아치각에서 즉각 나타 나고 좌우에서 모두 나타남을 볼 때 등 근막이완요법과 관련성이 높다는 것을 알 수 있다. 실제로 아치각은 발반사구 이론에서 척 추와 관련된 위치이며, Song et al. (2010)의 연구에서도 본 연 구결과와 동일하게 등 근막관리로 좌우 발의 아치각 값이 커졌다 고 보고되었다.

7) 모지각에 대한 변화 비교

등 근막이완요법이 왼발의 모지각에 미치는 영향을 알아보기 위해 기술통계와 반복측정 이원분산분석을 실시하였다. 기술통 
계를 통해서는 50-60대가 30-40대보다 모지각이 크다는 것과 $30-40$ 대의 주 1 회군과 주 2 회군은 모두 순차적으로 모지각이 감 소한다는 것을 알 수 있었다(Figure $6 \mathrm{~A}$ ). 반복측정 이원분산분 석의 결과에서는 측정 시기 $(F=6.312 ; p<0.01)$ 에서 주 효과가 나 타났기에 통계적 유의성을 알아보기 위해 Bonferroni로 조정된 다중비교를 시행하였다. 실험 전과 실험 6 회 사이에 차이가 존재 하여 실험의 효과가 나타났음을 알 수 있었다(Table 2). 이에 반 해 연령, 관리 빈도의 주 효과와 연령과 관리 빈도의 상호작용효 과, 측정 시기와 연령의 상호작용효과, 측정 시기와 관리 빈도의 상호작용효과, 측정 시기 및 연령과 관리 빈도의 상호작용효과는 통계적으로 유의미한 결과가 보이지 않았다(Appendix 13).

오른발의 모지각에 대한 기술통계를 살펴보면, 30-40대와 50-60대 모두 실험 전에서부터 6회 이후까지 순차적으로 감소 하였는데 30-40대 주1회군에서 가장 크게 변화하였다(Figure $6 \mathrm{~B})$. 반복측정 이원분산분석의 결과에서는 측정 시기 $(F=6.502$; $p<0.01)$ 에 따른 주 효과가 나타났다. 이에 Bonferroni로 조정된 다중비교를 통해 통계적 유의성을 살펴본 결과, 실험 전과 실험 6 회 간에 차이가 존재하여 실험에 따른 효과가 나타났음을 알 수 있었다(Table 2). 이에 반해 연령, 관리 빈도의 주 효과와 연령과 관리 빈도의 상호작용효과, 측정 시기와 연령의 상호작용효과, 측정 시기와 관리 빈도의 상호작용효과, 측정 시기 및 연령과 관 리 빈도의 상호작용효과에서는 통계적 유의성이 보이지 않았다 (Appendix 14).

이를 통해 등 근막이완요법이 모지각의 변화에 영향을 준다는 것을 알 수 있었다. 모지각도 아치각과 함께 발반사구에서 척추 에 대응하는 위치에 있어 등과 발의 특정 부위가 관련 있음을 확 인할 수 있었다. 그리고 Song et al. (2010)의 연구와 같이 본 연 구에서도 모지각이 유의하게 감소하였다.

\section{8) 족선각에 대한 변화 비교}

등 근막이완요법이 왼발의 족선각에 미치는 영향을 알아보기 위해 기술통계와 반복측정 이원분산분석을 실시하였다. 결과를 보면 연령, 관리 빈도, 측정 시기의 주 효과와 연령과 관리 빈도 의 상호작용효과, 측정 시기와 연령의 상호작용효과, 측정 시기 와 관리 빈도의 상호작용효과, 측정 시기 및 연령과 관리 빈도의 상호작용효과 모두에서 통계적으로 유의미한 차이가 나타나지 않았다(Appendix 15). 오른발의 족선각에서도 효과에 대한 측정 항목들에서 통계적인 유의성이 보이지 않았다(Appendix 16).

이와 같은 결과는 Song et al. (2010)의 연구와 상반되는 결과 로 선행 연구가 10 회 관리 횟수였는데 반해 본 연구에서는 6 회로 진행되었다는 점에서 비롯한 것으로 짐작된다. 따라서 시행에 따 른 효과를 측정하기 위해서는 시행 횟수가 중요함을 알 수 있었 다.
9) 외번각에 대한 변화 비교

등 근막이완요법이 왼발의 외번각에 미치는 영향을 알아보 기 위해 기술통계와 반복측정 이원분산분석을 실시하였다. 결 과는 연령, 관리 빈도, 측정 시기의 주 효과와 연령과 관리 빈도 의 상호작용효과, 측정 시기와 연령의 상호작용효과, 측정 시기 와 관리 빈도의 상호작용효과, 측정 시기 및 연령과 관리 빈도의 상호작용효과가 통계적으로 유의미하지 않은 것으로 나타났다 (Appendix 17).

이와 달리 오른발의 외번각은 효과가 나타났다. 먼저 기술통계 를 살펴보면, 30-40대와 50-60대 모두 실험 전과 실험 후 간에 외번각이 증가하였다(Figure 7). 반복측정 이원분산분석의 결과 에서는 측정 시기 $(F=5.615 ; p<0.01)$ 의 주 효과가 나타났다. 통 계적 유의성을 알아보기 위해 Bonferroni로 조정된 다중비교를 시행하였는데, 실험 전과 실험 1 회 사이와 실험 전과 6 회 간의 차이는 존재하지만 실험 1 회와 실험 6 회 사이의 유의성은 나타나 지 않았다. 이것으로 실험 1 회에서 나타난 효과가 6 회까지 지속 되었다는 것을 알 수 있다(Table 2). 이에 반해 연령, 관리 빈도 의 주 효과와 연령과 관리 빈도의 상호작용효과, 측정 시기와 연 령의 상호작용효과, 측정 시기와 관리 빈도의 상호작용효과, 측 정 시기 및 연령과 관리 빈도의 상호작용효과에서는 통계적으로 유의미한 차이가 보이지 않았다(Appendix 18).

이와 같은 결과는 Song et al. (2010)의 연구에서 좌우 발에 모두 유의한 변화가 있었던 것과 차이가 있으며 시행된 횟수의 차이에 의한 것으로 추측된다.

\section{$\overline{\text { Conclusion }}$}

본 연구는 등 부위에 근막이완요법을 시행한 후 발 형태의 변화가 있는지를 알아보고자 하였다. 결과를 통해서 등 근막 이완요법이 발 형태를 변화시킨다는 것을 알 수 있었다. 족문 에서 종골폭 및 아치각과 모지각은 왼발과 오른발 모두에서 측정 시기에 따른 차이가 나타났다. 족장 $\mathbb{I}$, 종골각, 외번각 은 오른발에서만 유의미한 차이가 존재하였는데 왼발에서만 유의미한 차이가 존재하는 결과가 없는 것은 눈여겨볼 만하 다. 그리고 족장 I, 족폭, 족선각에서는 두 발 모두에서 유의 미한 차이가 존재하지 않았다.

연구 결과에서 측정 시기에 따른 유의성은 관찰되었지만 관 리 빈도와 연령에 따른 유의성은 나타나지 않아 연령과 관리 빈도에 관계없이 시행 자체가 가지고 있는 효과를 알 수 있었 다. 이를 통해 성인 여성들은 등 관리를 통해 등뿐만 아니라 발 관리의 효과를 누릴 수 있으며 시간과 경제적 상황에 따라 최적의 관리 계획을 세울 수 있다. 또한 발반사와 근막경선이 론에 따른 인체의 유기적 관계를 동시에 확인할 수 있었다. 
지금까지 연구를 살펴보면 등 부위의 관리를 통해 족문의 변화를 살펴본 연구도 드물었지만 스웨디쉬나 경락 등의 기법 을 시행한 후 족문의 변화를 관찰한 연구도 제대로 이루어지 지 않고 있다. 이에 시행 기법에 따른 연구와 성별에 따른 연 구의 필요성을 제기하며 향후 등과 발의 유기적 관계에 대한 심도 있는 연구들이 활발히 진행되길 바란다.

This work is part of the Mijung Kim's M.S. thesis at the Youngsan University, Busan, Korea.

\section{References}

Ahn SJ, Hwang JH, Choi JE, Cho JH, Jang JB, Lee KS. Practical use of HRV as barometer of climacteric symptom. The Journal of Oriental Obstetrics \& Gynecology, 18: 192202, 2005.

Clarke $\mathrm{HH}$. An objective method of measuring the height of the longitudinal arch in foot examinations. Research Quarterly for Exercise and Sport, 4: 99-107, 1933.

Ham YW. Myofascial release for muscle tension. Journal of Allied Health Research, 8: 15-25, 1999.

Heo JR, Song H, Park JG, Hong JG, Kim JR, Lee DJ, Jeon YS, Park SY, Choi SY, Kim EA. Foot reflexology massage. Hyungseul Publishing, Paju, p13, 2013.

Hwang J, Lee JH. Women's employment, fertility and growth in Korea: an empirical analysis for 16 cities and provinces. Journal of Economics Studies, 30: 19-43, 2012.

Hyong IH. A study of foot shape and low back pain, hip abduction muscle and ankle lateral injury. Journal of the Korean Society of Physical Medicine, 3: 127-133, 2008.

Jeong IS. Reflexology: health at your fingertips. Book21 Publishing, Paju, pp15-16, 2004. (Kunz B, Kunz K. 2003.)

Jung SJ, Kim SM, Yi DH, Kang SM. Effects of myofascial massage on the skin care of middle aged women. Asian Journal of Beauty and Cosmetology, 7: 11-22, 2009.

Kang SH, Lim Bl. The inequality and the polarization of after-retirement income and redistribution effect of public pension on the income of the old-aged. Korean Social Security Studies, 25: 55-85, 2009.
Kim DH, Kim TH, Jung DY, Weon JH. Effects of the graston technique and self-myofascial release on the range of motion of a knee joint. Journal of the Korean Society of Physical Medicine, 9: 455-463, 2014.

Kim EJ, Kim EH. A study on the foot from trough footprint university students in Daejeon-Chung buk. Asian Journal of Beauty and Cosmetology, 1: 57-69, 2003.

Kim M. A comparative study of the factors effecting on marital satisfaction by age cohort. Korean Journal of Family Welfare, 26: 35-62, 2009.

Kim SY, Bae HS. Influence of back massage upon facial skin condition and stress relaxation in middle aged women. Jounal of the Korean Society of Cosmetology, 18: 569578, 2012.

Park SJ, Choi EY. Relationships among hwabyung, depression and quality of life in middle-aged women. The Journal of Asian Women, 53: 167-188, 2014.

Ryu S, Han M. Differences of subjective well-being (SWB) and variables related to SWB among generations in Korean women. Gender and Culture, 9: 45-73, 2016.

Seo DC, Choi TB, Chae SH. The effect of myofascial release on the alleviation of pain: revolve around upper trapezius muscle of piano player. Asian Journal of Beauty and Cosmetology, 8: 63-70, 2010.

Seo HK, Han JM, Lee DH. The effects of myofascial release therapy on blood velocity of cranial arteryin tensiontype headache subjects. The Journal of Korean Academy of Orthopedic Manual Physical Therapy, 8: 5-17, 2002.

Seo HS, Sohng KY. The effect of footbaths on sleep and fatigue in older Korean adults. Journal of Korean Academy of Fundamentals of Nursing, 18: 488-496, 2011.

Song HS, Kim H, Chin $\mathrm{CH}$. A study on the changes in foot shape after caring back muscle fascia. Asian Journal of Beauty and Cosmetology, 8: 63-72, 2010.

Song YG, Lee JS, Lim HH, Cho NG. Anatomy trains: myofascial meridians for manual and movement therapists. Hyunmoon Publishing, Seoul, pp22-29, 2005. (Myers TW. 2001.)

Yoon IS, Choi HJ. Effects of foot massage at the abdominal area reflex point on the electroencephalogram. Asian Journal of Beauty and Cosmetology, 11: 495-503, 2013. 


\section{국문초록}

\section{등 근막이완요법이 30-60대 성인 여성의 발 형태에 미치는 영향}

김미정 ${ }^{1}$, 박세연 ${ }^{2}$, 오수연 ${ }^{3 *}$

${ }^{1}$ 동덕여자대학교 보건향장학과, 서울, 한국

${ }^{2}$ 동덕여자대학교 응용화학과, 서울, 한국

${ }^{3}$ 영산대학교 미용예술학과, 부산, 한국

목적: 본 연구는 등 근막이완요법이 30-60대 성인 여성들의 발 형태에 영향을 미치는지를 살펴보고 관리 빈도와 연령에 따른 차이 가 있는지도 알아보고자 하였다. 방법: 부산에 거주하는 30-60대의 건강한 여성 34명을 관리 빈도(주1회, 주2회)에 따라 분류하고, 연령에 따라 30-40대와 50-60대로 구분하여 등 근막이완요법을 6회씩 진행하였다. 실험 전후에 족문을 찍어서 발의 형태 변화를 확인하였다. 족문을 통해 족장 I, 족장 II, 족폭, 종골폭, 종골각, 아치각, 모지각, 족선각, 외번각을 구하였다. 자료분석은 Statistical Package for the Social Sciences (SPSS) 20.0을 이용하여 독립 $t$ 검정과 기술통계, 반복측정 이원분산분석을 실시하였다. 결과: 등 근막이완요법을 진행한 후 족문에 변화가 나타났다. 종골폭 $(p<0.01 ; p<0.001)$, 아치각 $(p<0.001 ; p<0.01)$, 모지각 $(p<0.01 ; p<0.01)$ 은 왼발, 오른발 모두에서 측정 시기에 따라 통계적 유의성이 나타났고, 족장 II $(p<0.05)$, 종골각 $(p<0.05)$, 외번각 $(p<0.01)$ 은 오른발 에서 유의미한 차이가 보였다. 그러나 족장 I, 족폭, 족선각에서는 유의한 변화가 보이지 않았다. 또한 연령과 관리 빈도에 따른 효 과도 나타나지 않아 성인 여성들에게 등 근막이완요법이 연령과 관리 빈도에 관계없이 효과가 있음을 알 수 있었다. 결론: 등 근막 이완요법은 성인 여성의 발 형태에 변화를 주며 특히, 발의 척추 반사구와 관련성이 높음을 알 수 있었다.

핵심어: 근막, 반사구, 족문, 아치각, 모지각

\section{참고문헌}

강성호, 임병인. 노후소득의 불평등 및 양극화와 공적연금의 개선효과. 사회보장연구, $25: 55-85,2009$.

김도현, 김태호, 정도영, 원종혁. 글라스톤 기법을 이용한 연부조직가동술과 자가근막이완술이 넙다리뒤근 유연성에 미치

는 영향. 대한물리의학회지, 9: 455-463, 2014.

김미령. 연령대에 따른 여성의 결혼만족도 차이 및 영향요인 비교. 한국가족복지학, 26: 35-62, 2009.

김수영, 배현숙. 등 마사지가 중년여성의 안면피부상태 및 스트레스 완화에 미치는 영향. 한국미용학회지, 18: 569-578,

2012.

김은자, 김은희. 족문을 통한 일부 대학생의 발의 형태에 관한 연구. 아시안뷰티화장품학술지, 1: 57-69, 2003.

류승아, 한민. 한국 여성의 연령별 행복수준 비교와 관련 변인들. 젠더와 문화, 9: 45-73, 2016.

박선정, 최은영. 중년 여성의 화병과 우울 및 삶의 질과의 관계. 아시아여성연구, 53: 167-188, 2014.

서동천, 최태부, 채수형. 근막이완 요법이 통증 완화에 미치는 영향: 피아노 연주자의 상부 승모근을 대상으로. 아시안뷰티 화장품학술지, 8: $63-70,2010$.

서현규, 한종만, 이동호. 긴장형 두통환자에서의 근막이완술이 뇌혈류 속도에 미치는 영향. 대한정형도수물리치료학회지,

8: 5-17, 2002.

서희숙, 송경애. 족욕요법이 한국노인의 수면과 피로에 미치는 효과. 기본간호학회지, 18: 488-496, 2011.

송윤경, 이종수, 임형호, 조남경. 근막경선 해부학. 현문사, 서울, pp22-29, 2005. (마이어스 토마스 W. 2001.)

송하순, 김훈, 진정화. 등 근막관리 후의 발 변화 연구. 아시안뷰티화장품학술지, 8: 63-72, 2010.

안수정, 황재호, 최정은, 조정훈, 장준복, 이경섭. 갱년기 증상의 척도로서의 심박 변이도의 활용에 관한 연구. 대한한방부

인과학회지, 18: 192-202, 2005. 
윤임실, 최현주. 발마사지에서 복부부위 반사구가 뇌파에 미치는 영향. 아시안뷰티화장품학술지, 11: 495-503, 2013.

정순조, 김수미, 이동희, 강상모. 근막이완 마사지가 중년여성의 피부에 미치는 영향. 아시안뷰티화장품학술지, 7: 11-22, 2009.

정인수. (내 몸이 가벼워지는) 손발 마사지. 21세기북스, 파주, pp15-16, 2004. (쿤즈 바바라, 쿤즈 케빈. 2003.)

함용운. 근긴장의 근막이완. 보건과학연구논집, 8: 15-25, 1999.

허정록, 송환, 박준기, 홍재기, 김주리, 이동자, 전영선, 박서연, 최순영, 김은애. 발반사요법과 마사지. 형설출판사, 파주, $\mathrm{p} 13,2013$.

형인혁. 발의 형태와 요통, 고관절 외전 근육, 발목관절 외측손상에 관한 연구. 대한물리의학회지, $3: 127-133,2008$.

황진영, 이종하. 한국에서 여성의 고용, 출산 및 성장 간의 상호관련성: 16 개 시도의 패널자료를 이용한 실증분석. 경제연 구, 30: 19-43, 2012. 


\section{中文摘要}

\section{背筋膜松弛疗法对30-60岁成年女性足部形态的影响}

金美貞 ${ }^{1}$, 朴世蓮 ${ }^{2}$, 吳壽連 $^{3 *}$

${ }^{1}$ 同德女子大学保健香妆学科, 首尔, 韩国

${ }^{2}$ 同德女子大学应用化学科, 首尔, 韩国

灵山大学美容艺术学科, 釜山, 韩国

目的: 探讨背筋膜松弛疗法是否会影响30-60岁成年女性的足部形态, 并探讨根据背筋膜治疗频率和参与者年 龄是否具有差异。方法: 对居住在釜山的30-60岁的健康女性，根据治疗频率（每周一次，每周两次）和年龄 分组, 进行六次背筋膜松弛治疗。足迹是在实验前和实验后进行, 并确认足部形态变化。通过足迹, 测定脚长 I、脚长II、脚宽、跟骨宽度、倾角、拱角、拇角、束角以及外翻角。采用Statistical Package for the Social Sciences（SPSS）20.0进行独立样本t检验, 描述性统计和重复测量的双向方差分析。结果: 背筋膜松弛疗 法进行后, 足迹产生变化。根据测量时间, 跟骨宽度 $(p<0.01, p<0.001)$ ，拱角 $(p<0.001, p<0.01)$ 以及拇角 $(p<0.01, p<0.01)$ 在左右两脚都产生了统计意义的差异。此外, 足长II $(p<0.05)$ ，倾角 $(p$ $<0.05)$ 以及外翻角 $(p<0.01)$ 在右脚产生了统计意义的差异。然而, 在足部长度、、脚宽、束角方面没有显 著变化。此外, 根据年龄和治疗频率, 不产生差异, 因此对于成年女性不管年龄和治疗频率, 背筋膜疗法都具 有效果。结论: 背部筋膜松弛疗法改变了成年女性的足部形态, 并被认为与足部的脊髓反射密切相关。

关键词: 筋膜, 反射, 足迹, 拱脚, 拇角 